Böhm-Kasper, Oliver; Dizinger, Vanessa; Gausling, Pia

\title{
Multiprofessional collaboration between teachers and other educational staff at German all-day schools as a characteristic of today's professionalism
} International journal for research on extended education : IJREE 4 (2016) 1, S. 29-51

Quellenangabe/ Reference:

Böhm-Kasper, Oliver; Dizinger, Vanessa; Gausling, Pia: Multiprofessional collaboration between teachers and other educational staff at German all-day schools as a characteristic of today's professionalism - In: International journal for research on extended education : IJREE 4 (2016) 1, S. 29-51 - URN: urn:nbn:de:0111-pedocs-228977 - DOI: 10.25656/01:22897

https://nbn-resolving.org/urn:nbn:de:0111-pedocs-228977

https://doi.org/10.25656/01:22897

in Kooperation mit / in cooperation with:

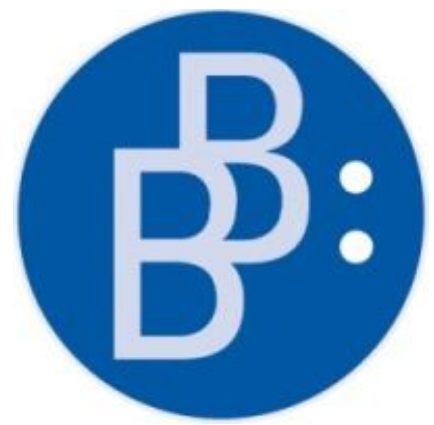

https://www.budrich.de

\section{Nutzungsbedingungen}

Dieses Dokument steht unter folgender Creative Commons-Lizenz: http://creativecommons.org/licenses/by-nc-nd/3.0/de/deed - Sie dürfen das Werk bzw. den Inhalt unter folgenden Bedingungen vervielfältigen, verbreiten und öffentlich zugänglich machen: Sie müssen den Namen des Autors/Rechteinhabers in der von ihm festgelegten Weise nennen. Dieses Werk bzw. dieser Inhalt darf nicht für kommerzielle Zwecke verwendet werden und es darf nicht bearbeitet, abgewandelt oder in anderer Weise verändert werden.

Mit der Verwendung dieses Dokuments erkennen Sie die Nutzungsbedingungen an.

\section{Terms of use}

This document is published under following Creative Commons-License: http://creativecommons.org/licenses/by-nc-nd/3.0/de/deed.en - You may copy, distribute and transmit, adapt or exhibit the work in the public as long as you attribute the work in the manner specified by the author or licensor. You are not allowed to make commercial use of the work or its contents. You are not allowed to alter, transform, or change this work in any other way.

By using this particular document, you accept the above-stated conditions of use.

\section{Kontakt / Contact:}

peDOCS

DIPF | Leibniz-Institut für Bildungsforschung und Bildungsinformation Informationszentrum (IZ) Bildung

E-Mail: pedocs@dipf.de

Internet: www.pedocs.de

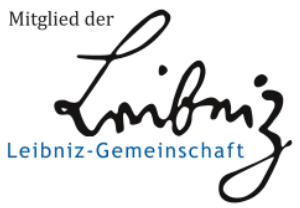




\title{
Multiprofessional Collaboration Between Teachers and Other Educational Staff at German All-day Schools as a Characteristic of Today's Professionalism
}

\author{
Oliver Böhm-Kasper, Vanessa Dizinger \& Pia Gausling
}

\begin{abstract}
The present article uses two empirical studies to look at multiprofessional collaboration between teachers and other educational staff at German all-day schools. A quantitative study is used both to develop an instrument for the measurement of multiprofessional collaboration and to analyse the connections between collaborative action and characteristic features of the teaching staff. Additionally, a qualitative study throws light on the extent, challenges and evaluation of multiprofessional collaboration at all-day schools. The two studies point to the fact that multiprofessional collaboration is underdeveloped at German all-day schools as well as to future challenges for closer collaboration between teachers and other educational staff.
\end{abstract}

Keywords: collaboration, professionalism, teachers, all-day staff, all-day school

\section{Introduction}

The German school system used to be characterised mostly through Halbtagsschulen (where teaching takes place from 8 am to $1 \mathrm{pm}$ ). Since 2000, however, Germany has undergone a substantial programme in which new all-day schools were developed and already existing ones were expanded. An all-day school is a school with an allday programme form (mostly from 8 am to $5 \mathrm{pm}$ ) consisting of the instruction time plus extended education and leisure-time offerings. In addition to regular instruction, an all-day school provides morning, lunchtime, and afternoon education and care. As to their formal organization, a distinction is made between all-day schools with "open", "compulsory", and "partially compulsory" all-day attendance ("offene", "gebundene" and "teilweise gebundene" Ganztagsschule). The compulsory attendance all-day school has obligatory school hours in the morning and afternoon, in part rhythmic, for all students. In the partially compulsory form of all-day school attendance is only for a part of students (e.g. individual classes or different grades) obligatory. The open all-day school has regular hours of school instruction (mostly in the morning) plus optional offerings attended by a part of the students, mostly concentrated on lunch, games, sports, recreational activities and homework help from 
teachers and other educational professionals. These extracurricular activities can be provided by the school or an outside organization (cf. Schüpbach \& von Allmen, 2013, p. 19).

All-day schools differ from half-day schools not only by extending the school day, but also by a different composition of the staff: At half-day schools the staff consist almost exclusively of teachers. In some half-day schools also social workers or professionals for children with special needs are employed. In contrast, all-day schools are characterised by an obligatory multiprofessional composition of the educational team. While the regular hours of school instruction are held by the teachers, the optional offerings are provided by other educational staff members. This staff varies from specialists with professional pedagogic training to employees with non-educational background.

These new forms of all-day education turned a high proportion of German schools (55.9\% in 2012, Autorengruppe Bildungsberichterstattung, 2014), which used to be the exclusive work place of teachers, into institutions with different professions, thus offering chances at multiprofessional collaboration (Speck et al., 2011).

There are many ways in which multiprofessional collaboration at all-day schools seems necessary and desirable. Among other issues, more intensive collaboration between educational staff aims to the appropriate support of students. Another aspect that makes these multiprofessional cooperative activities necessary is the goal of shaping schools into promising places of joint learning and living (e.g., Steiner, 2010; Holtappels, Krinecki, \& Menke, 2013; Knauer, 2010). As a result, collaboration of different educational actors may enhance schools' external relationships and the relevance of school topics for the students' living conditions.

Furthermore, increasing collaboration between different professional groups has given an influence to the debate about the professionalism as well as the professionalization of teachers and the other educational staff at all-day schools. Accordingly, people in the teaching profession can use team work to advance their own skills and abilities. In addition, collaborating partners can experience some relief in their work through synergies, and better solutions to more complex problems can be found (e.g., Hord, 1997; Reh, 2008). On the other hand, review of recent research shows non-negligible problems in the communication, participation and coordination between different educational actors at all-day schools (e.g., Arnoldt, 2009; Holtappels, Klemm, \& Rolff, 2008; Beher \& Rauschenbach, 2006). First of all, problems originate from the different organizational embedding of several educational professions.

The other educational staff members at all-day schools work on the basis of different labour standards, work time regulations and labour contract periods than teachers. This in turn leads to a not inconsiderable need for coordination and organization within schools (Steiner, 2010). Secondly, the collaboration between members of different educational professions is connected with various and partly conflicting understandings of educational objectives. The perception of a lack of recognition by one professional group seems to endanger multiprofessional team building processes sustainably. Not only multiprofessional collaboration, but cooperation in general can also be a stress factor. However, only a perceived value added through collaboration does justify the effort or additionally invested time (Böhm-Kasper, Dizinger, \& Heitmann, 2013; Lütje-Klose \& Urban, 2014). 
Despite these challenges for a successful collaboration between teachers and the other educational staff, cooperation is considered to be the means of choice for the establishment of a successful teaching and learning culture in all-day schools (Horstkemper, 2011).

This article will first present a newly developed measurement of multiprofessional collaboration as well as features that may contribute to intensive multiprofessional actions. Secondly, the challenges and difficulties of collaboration between different professional groups, which result from different backgrounds and different professional self-concepts, will be explored. In this context, we will also look at the emerging goals and the impact of multiprofessional collaboration. The overall research question of both studies conducted in a mixed methods design is therefore twofold: In what manner is multiprofessional collaboration in all-day schools realized and what are the challenges and opportunities of collaborative work between teachers and the other educational staff?

\section{Literature Review}

\section{Teacher Professionalism at All-day Schools}

Collaboration as a characteristic of teacher's professionalism is a broadly discussed issue. To pose the question of teacher professionalism is to ask the wider question of what qualifications, knowledge and capacities are necessary to meet professional requirements (Englund, 1996). This is obviously related with a discussion of professionalization which, in contradistinction to professionalism, can be understood as a process aiming to give a certain group the necessary qualifications or to enable them to tackle the challenges of their professional activities (Whitty, 2000).

There is a great number of studies on teacher professionalism which reflect the multiple and controversial discourses in this field (e.g. Demirkasımoğlu, 2010). In contrast, it is hardly possible to raise the question of the professionalism of the educational staff as a group. The reason for this is that teachers belong to a clearly defined group on the basis of governmental rules and regulations concerning education, entry qualifications, employment and remuneration - while the other educational staff at all-day schools belong to a heterogeneous group. This group varies from specialists with professional pedagogic training to employees with non-educational degrees or even with no (educational) background specific to the profession (e.g. Dizinger, 2015).

In order to illustrate the features of professional action and the place that collaboration has in the context of professionalism, we will first identify features of teacher professionalism, not least because this corresponds to the major perspective adopted also in our research. Sachs (2003) formulated five core elements of teacher professionalism which are not distilled from governmental guidelines but do justice to the specific nature and the demands of a teacher's job. One of these core elements is collaboration which encompasses two aspects. The first is the collaboration and the joint construction of profession-related knowledge by the teachers within one 
school. The other aspect is that such collaboration also includes other actors within and outside the school who develop their own competences and those of the teachers in the same extent through cooperative action. A further core element of teacher professionalism is cooperation in the wider sense which can help to relax the restrictions from which the teaching profession suffers (no real specialist language, no technology to document and discuss successful educational practice and its impact), and to get a dialogue between professional actors under way that is oriented towards critical reflection of their practice. These principles are ideally suited for work at German all-day schools as a fruitful common platform for the debate of the professional self-image of teachers and other educational staff.

\section{Multiprofessional Collaboration at All-day Schools}

Multiprofessional collaboration can be defined as a collaborative act of two or more professionals from different professional groups who work in the education sector. This must be distinguished from professional collaboration at schools which refers to the collaboration of members of the same profession, e.g. teachers.

From the perspective of the theory of collaboration, the core element of any collaborative act is the common goal or task (Gräsel, Fussangel, \& Pröbstel, 2006): "Collaboration is characterised by the reference to other goals or tasks that are to be jointly achieved; it is intentional, communicative and needs trust. It presupposes a certain measure of autonomy, and is committed to the norm of reciprocity" (Spieß, 2004, p. 199).

Besides this shared task or goal, there are other central characteristic features that are equally important for the definition of collaboration, one of them being the maintenance of the autonomy of the individual and the other trust and reciprocity (Böhm-Kasper, Dizinger, \& Heitmann, 2013; Dizinger, 2015; Gräsel, Fussangel, \& Pröbstel, 2006; Reh \& Breuer, 2012). Using these features and having recourse to the model of professional teacher collaboration according to Gräsel, Fussangel and Pröbstel (2006), three levels of multiprofessional collaboration can be differentiated (Böhm-Kasper, Dizinger, \& Heitmann, 2013):

(1.) The simplest form of collaboration is the mutual exchange of materials and information. This can serve to provide the multiprofessional collaborators with identical information; teachers and other educational staff can, for example, exchange information about certain events that took place in the morning or the afternoon. That is more of a low-cost collaboration, and in order to implement this form of cooperation it is sufficient for the collaborating partners to share general goals and have a modicum of trust in one another. Individual autonomy is also largely preserved.

(2.) Division of labour is a somewhat closer form of collaboration. An example is furnished by teachers dividing up thematic project work among themselves or take over parts of a conversation with parents according to their professional expertise. This form makes an agreement about common goals, division of tasks and the aggregation of results necessary in order to achieve the goals set. In addition, a certain degree of trust that the cooperating partners will carry out their part of the task is 
necessary. The cooperating partners retain, however, most of their autonomy while working on the task.

(3.) Co-construction is to be understood as the closest form of collaboration in which a common knowledge base is constructed and common problem solutions are made possible. In co-constructive collaboration, for example, a multiprofessional steering team may develop common goals and standards for the organization of an all-day school, or a teacher and a social worker may work in a pair to produce supporting measures for individual students.

With this close form of collaboration, goals and tasks need to be determined together at least in part which makes great trust in one another absolutely essential, and the autonomy of the individual cooperating partners can be restricted.

As for the discourse on professionalism and collaboration, it should be remembered that co-constructive forms of work have the potential to develop one's own abilities and knowledge, to reflect on one's own educational actions and make use of extended collective opportunities for action in one's everyday teaching life (e.g., Gräsel, Fussangel, \& Pröbstel, 2006; Reh, 2008). According to Sachs (2003), these forms of close collaboration are an integral part of professional action (cf. section 2.1). They have, however, also a higher potential for conflict than simpler forms of collaboration. Differences in professional affiliation, for example because of diverging professional self-images, different institutional embeddedness or hierarchical positions, are plain to see and have to be overcome first if collaboration is to be successful (e.g., Reh \& Breuer, 2012; Maykus, 2009).

\section{Multiprofessional Collaboration at All-day Schools - Taking Stock of Empirical Studies}

The findings of current qualitative and quantitative studies on the implementation of multiprofessional collaboration at German all-day schools seem to indicate that multiprofessional collaboration is an ongoing process (e.g., Beher et al., 2007; Böttcher et al., 2011; Tillmann \& Rollett, 2011). Thus, there seems to be a clear division of labour between teachers and the other educational staff in their current everyday activities. Böttcher et al. (2011), for instance, report that the two groups see themselves as groups with different functions and act within their allotted domains (teaching versus Ganztagsbereich [work in the all-day sector]).

Given this division in terms of tasks and functions, it seems reasonable for empirical investigations to propose the hypothesis that multiprofessional collaboration as well as professional reflection on the part of teachers is directed exclusively towards global tasks and goals, such as the holistic support of students (Dizinger, 2015).

The results mentioned above can also be identified in other studies on extended education: In the following, some findings of a study by Dahl \& Karlsudd (2015), which focuses on the professional role of pedagogues in Swedish leisure-time centres, are presented. The leisure-time centre in Sweden is comparable to the concept of an "all-day-school" in Germany (Klerfelt \& Haglund, 2014, p. 45). The study by Dahl \& Karlsudd (2015) shows that it is important for the leisure-time pedagogues to see themselves and the teachers as different professional groups with different 
tasks and knowledge: "All informants state that it is important to point out that the leisure-time teacher's profession cannot be confused with the teacher who has the traditional teaching mission. The informants claim to have their own knowledge [...]“ (Dahl \& Karlsudd, 2015, p. 27).

Moreover, the closer connection between the mission of the leisure-time centres and the school activity (cf. Dahl \& Karlsudd, 2015, p. 23; Andersson, 2010) leads to a clearer professional identity and to a higher occupational status: "The leisure-time teachers have acquired higher status by being a clearer part of a common educational organization. They share the curriculum, and they have received other tasks in the school" (Dahl \& Karlsudd, 2015, p. 32). Therefore, such a connection between different fields of education can have a positive effect on the respective profession and on the distinction from other professional groups. Even though leisure-time centres can be compared to the concept of the all-day school in Germany, these findings are contradictory to the idea and the objective of multiprofessional collaboration at all-day schools. In comparison, a close linkage between curricular and extra-curricular content has rarely been noted in Germany. Nevertheless, where this linkage between morning and afternoon offerings does exist, it seems to further more intensive multiprofessional collaboration (e.g., Böhm-Kasper, Dizinger, \& Heitmann, 2013; Holtappels, Krinecki, \& Menke, 2013).

Research from Switzerland about collaboration in schools (Tagesschulen) shows that different forms of connections between curricular and extra-curricular areas exist (cf. Jutzi, Schüpbach, \& Thomann, 2013, p. 96; Forrer \& Schuler, 2010).

Besides, an evaluation of all-day schools in Zurich by Forrer \& Schuler (2010) found out that the type of school (open all-day school or compulsory all-day school) has an influence on the collaboration between teachers and other educational professionals. At open all-day schools the other educational professionals were mainly responsible for the extended educational offerings. At compulsory all-day schools teachers and the other educational staff worked closely together (cf. Schüpbach \& von Allmen, 2013, p. 26). Thus, the structure of school (open versus compulsory all-day school) plays an important role in the realization and the intensity of collaboration.

Empirical investigations in English-speaking countries, which analyse "multiprofessional collaboration or interprofessional collaboration", refer mainly to research in health care (e.g. collaboration between trainees in the health professions and youth and children at school; Ogenchuk, Spurr, \& Bally, 2014) or to research on collaboration between teachers from different subject areas (e.g., Flowers, Mertens, \& Mulhall, 2000).

Furthermore, international research focuses primarily on the observation of multiprofessional teams that together look after students with disabilities (e.g., Tuomainen, Palonen, \& Hakkarainen, 2010) or children at risk (e.g., Hesjedal, Hetland, \& Iversen, 2013). Such teams are also not unknown at German all-day schools where the teams, for example, offer support to students at risk in so-called 'inclusive classes'.

In a typical case, we find a division of areas and tasks between teachers and other educational staff at German all-day schools (see the section above). Given this situation, it is far more difficult to identify the impact of multiprofessional collaboration. Thus, it is of little surprise that only few studies can give information on this issue. 
Research on the impact mostly investigates the effects of extended education and after-school programmes, for example the effects of extended education on student achievement (e.g. mathematics and language achievement; Schüpbach \& von Allmen, 2013) or the impact of after-school programme that can improve youths' personal and social skills and academic achievement (Durlak \& Weissberg, 2007; Bae \& Jeon, 2013).

Nevertheless, it can be reported - referring to the impact of multiprofessional collaboration -, that teachers as well as the other educational staff state a positive effect on their individual competencies under favourable conditions. Moreover, multiprofessional collaboration reduces the burden of the teachers because they can delegate some non-instructional tasks to the non-teaching staff (Böhm-Kasper, Dizinger, \& Heitmann, 2013).

All in all, there are only a few studies which focus on the collaboration between teachers and other pedagogical professionals.

Consequently, Schüpbach and von Allmen (2013) state that "[r]esearch on multiprofessional collaboration in all-day schools between teachers and other educational professionals is very new and just developing currently. [...] As a next step, there is a need for broader investigation by means of (intervention) studies with a longitudinal design on (development of) collaboration and on different effects of collaboration [...]" (p. 28).

Therefore, multiprofessional collaboration between teachers and the other pedagogical staff at all-day schools has been hardly investigated up to now.

\section{Research Questions}

Using two studies in a mixed methods design (Creswell \& Plano Clark, 2011), we will investigate the implementation of multiprofessional collaboration, including its evaluation, its shared goals and its impact from different perspectives.

\section{A Quantitative Study on Multiprofessional Collaboration Viewed From the Teachers' Perspective ${ }^{1}$}

Based on the results from the literature review mentioned and a previous qualitative study (Dizinger, Fussangel, \& Böhm-Kasper, 2011), a questionnaire was developed to assess the multiprofessional collaboration (with its different levels of collaborative action: exchange, mutual division of labour and co-construction). This procedure gave the opportunity to make multiprofessional collaboration at all-day schools measurable in quantitative terms and relate it to variables concerning conditions and impact.

1 The research project "Beanspruchungserleben und Formen der Lehrerkooperation" [Experiencing demands and forms of teacher collaboration] (Lead researchers: Prof. Böhm-Kasper, Prof. Gräsel, Prof. Weishaupt) was financially supported from 2008 to 2010 by a grant from the BMBF [Federal Ministry of Education and Research] and the EFS [European Social Fund for Germany]. 
First findings on the quantitative nature of multiprofessional collaboration and selected teacher characteristics were subjected to a cluster analysis in order to deduce features favourable to a greater degree of collaboration. The reason for this analysis was that it is precisely intensified collaboration that can be regarded as part of professional action. Therefore the research question can be formulated:

- RQ 1: What teacher characteristics facilitate more intensive collaboration?

\section{A Qualitative Study on Multiprofessional Collaboration and Professional Differences Viewed From the Perspectives of Both Teachers and Educators ${ }^{2}$}

The results of the first study were given a deeper analysis in a second, qualitative study. In an extension of the first study, this second study looked at multiprofessional collaboration from the perspectives of both teachers and educators. It was concerned not just with multiprofessional collaboration and its evaluation or favourable conditions. Rather, observed difficulties that had arisen, for example, because of professional differences between teachers and the other educational staff, were investigated, and the goals and impact of their mutual work were also explored:

- RQ 2: What tasks and functions do the teachers and the educators take on, and how do they mutually perceive their jobs?

- RQ 3: What are the challenges and difficulties that teachers and educators report about multiprofessional collaboration?

\section{Methods}

The general approach of our research employed a mixed methods design according to Creswell and Plano Clark (2011). We used an explanatory sequential design with a quantitative study in the beginning, followed up with a qualitative study to get more information about the characteristics of multiprofessional collaboration. Thus, the data gathered in the two studies were aggregated to achieve a broader and deeper understanding of the research object, i.e. we looked for possible convergences, mutual confirmation or overlaps.

\section{A Quantitative Study on Multiprofessional Collaboration Seen From the Teachers' Perspective}

The newly developed questionnaire on multiprofessional collaboration was tested by means of a quantitative cross-sectional study $(n=620)$ of teachers from secondary schools (ISCED-level 2). The test of the newly designed questionnaire was, howev-

2 The qualitative interview study "Interprofessionelle Kooperation an Ganztagsgrundschulen” [Interprofessional collaboration at all-day primary schools] (Lead researchers: Prof. Böhm-Kasper and Dr. Dizinger) was supported from 2011 to 2012 by a grant from the Faculty of Educational Science of the University of Bielefeld. 
er, only one part of our work, we also included scales relating to the type of both job and collaboration. Besides gathering socio-demographic data (e.g. sex and age), the two following features of the teachers surveyed were also taken into account in the analyses: teacher self-efficacy (Gerecht et al., 2007) and work engagement (following Čandová, 2005).

In addition, collaboration between teachers and other educational professionals was measured through the use of four scales, two of them focussing on exchange, while the other two focussed on more intensive types of collaboration (division of labour and co-construction). Further, a scale for shared goals between teachers (Fussangel, 2008) was also part of the evaluation.

\section{A Qualitative Study on Multiprofessional Collaboration and Professional Differences Seen From the Perspective of Teachers and Educators}

We conducted a qualitative study subsequent to the quantitative to gain an in-depth understanding of the phenomenon of multiprofessional collaboration. Our focus was on primary all-day schools, since multiprofessional collaboration here is the default state. The multiprofessional teams in primary all-day schools are composed of regular teachers and other educational staff (usually educators).

The link between the quantitative and the qualitative study in our explanatory sequential design must be seen less in comparable samples than as in the phenomenon of multiprofessional collaboration. Five primary schools (ISCED-Level 1) in a German city were asked to participate in a qualitative interview study on the topic of multiprofessional collaboration at all-day schools. Three of these operated open all-day (where students were free to take part in the afternoon programme) while the other two operated primarily compulsory all-day (where participation in the afternoon programme was obligatory for students).

Twelve guideline-based interviews were conducted in all. The interviews were digitally recorded and transcribed using a common transcription scheme.

With regard to ethical considerations and data privacy (Gläser \& Laudel, 2004; Lichtman, 2013), the participants were informed about the nature and the purpose of the study in advance. The interviewees gave their consent to the recording of the interview as well as to the use of their anonymized data for publications.

A comparison of the perspectives of teachers with that of other educational staff was at the core of the study: five teachers and seven all-day staff were interviewed. The interview guideline contained questions on multiprofessional collaboration, its conditions and impact as well as the exploration of the diverging areas of tasks and activities of the professions involved. The interview evaluation was carried out employing qualitative content analysis in accordance with Mayring (2008), with two independent researchers performing the categorization. 


\section{Results}

In the following, central results of the quantitative and qualitative study are presented.

\section{A Quantitative Study on Multiprofessional Collaboration Seen From the Teachers' Perspective}

It was the goal of this investigation to build up scales for multiprofessional collaboration and perform explorative analyses.

Three scales were derived from results of a previous qualitative study (Dizinger, Fussangel, \& Böhm-Kasper, 2011), of which two refer to the implementation of the collaboration: (1) the instruction-related exchange, and (2) the student-related exchange. The third scale was to measure (3) relief through collaboration. For the test of the trifactorial structure a confirmatory factor analysis for ordinal data was calculated (see Figure 1). The fit indices to judge the global model structure show an acceptable degree of adaptation to the model. The three factors of (1) instruction-related exchange, (2) student-related exchange and (3) relief through multiprofessional collaboration are closely related $(\phi 1,2=.70, \phi 1,3=.65, \phi 2,3=.96)$. In particular, the student-related exchange and the experience of relief are closely connected. A bifactorial model is, however, not superior to the trifactorial one (see the comparison of models in Table 1). Subsequent reliability analyses point to a good or very good internal consistency of the scales $\left(\alpha\right.$ instruction-related $=.85, \alpha_{\text {student-related }}=$ $.86, \alpha$ relief through collaboration $=.92$ ). 
Figure 1. CFA - Three dimensions of multiprofessional exchange

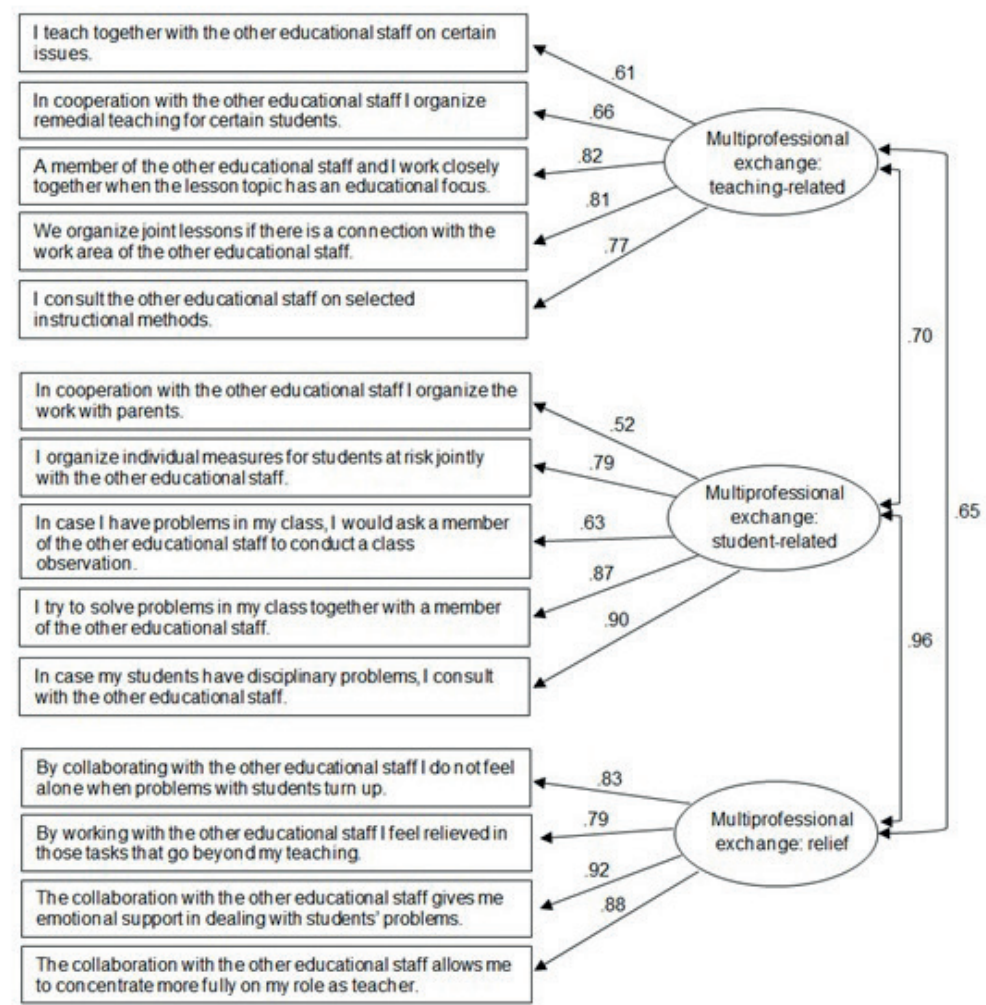

Note: Sample-N=544; $\mathrm{Chi}^{2}(74)=296.8 ; \mathrm{p}<.00 ; \mathrm{RMSEA}=.08 ; \mathrm{NFI}=.92 ; \mathrm{CFI}=.93$.

Table 1. Comparison of alternative CFA-models

\begin{tabular}{llllllll}
\hline & Df & AIC & BIC & Chisq & Chisq diff & DF diff & $\operatorname{Pr}(>$ Chisq $)$ \\
\hline 3-factor model & 74 & 22745 & 22939 & 472.87 & & & \\
2-factor model & 76 & 22776 & 22961 & 507.86 & 25.690 & 2 & $2.639 \mathrm{e}-06^{* * *}$ \\
Single-factor model & 77 & 23296 & 23477 & 1030.06 & 90.698 & 1 & $<2.2 \mathrm{e}-16^{* * *}$ \\
\hline
\end{tabular}

Explorative analyses show that, in parallel with the findings of the qualitative investigation followed up, forms of instruction-related exchange are hardly practiced at schools, while those of student-related exchange and the closely connected relief through collaboration are found slightly more frequently in everyday school life (see Table 2). 
Table 2. Descriptive statistics of multiprofessional exchange scales

\begin{tabular}{lllllll}
\hline Scale & Mean (SD) & MD & $\begin{array}{l}{[1 \text { st; 3rd }} \\
\text { Quartile] }\end{array}$ & Range & Skewness & Kurtosis \\
\hline ME: instruction-related & $2.12(1.06)$ & 1.8 & {$[1.2 ; 2.8]$} & $1-6$ & .99 & .43 \\
ME: student-related & $3.24(1.24)$ & 3.2 & {$[2.2 ; 4.2]$} & $1-6$ & -.04 & -.83 \\
ME: relief & $3.67(1.47)$ & 3.8 & {$[2.5 ; 4.8]$} & $1-6$ & -.18 & -1.06 \\
\hline
\end{tabular}

Note: $\mathrm{ME}=$ Multiprofessional exchange.

To resolve the question, what teacher characteristics have a favourable impact on more intensive collaboration, a cluster analysis (k-means-cluster) was conducted on the three scales for the multiprofessional collaboration. The aim was to analyse possible differences in the answer patterns of the teachers surveyed. The results of this cluster analysis show that the three-cluster solution provides an adequate mapping of the various answer patterns (see Figure 2).

Figure 2. Plot to determine the best number of clusters

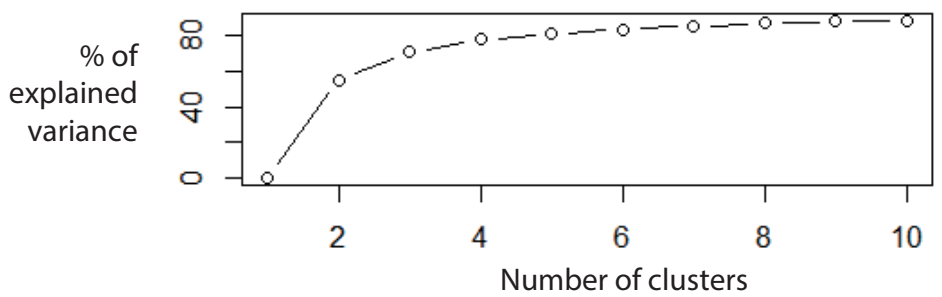

Using the mean values of the scales for multiprofessional collaboration to visualize cluster affiliation, the three clusters thus generated can be clearly distinguished by their content (see Figure 3): The members of cluster 1 are characterised by agreement that is clearly below average when compared to the statements presented on multiprofessional collaboration. They do not cooperate in matters relating to instruction or students with the members of the other educational staff. It is, therefore, not surprising that perceived relief through multiprofessional collaboration is rare. The members of cluster 2 reported slightly below-average collaboration with the other educational staff in teaching matters. By contrast, student-related collaboration is practiced more often. Relief through multiprofessional collaboration is also slightly above average. In cluster 3 teaching staff demonstrate clearly above average values in all three scales for multiprofessional collaboration. These teachers cooperate with members of the other educational staff in matters relating both to instruction and students. The perceived relief is correspondingly great. 
Figure 3. Mean values of multiprofessional collaboration by cluster affiliation

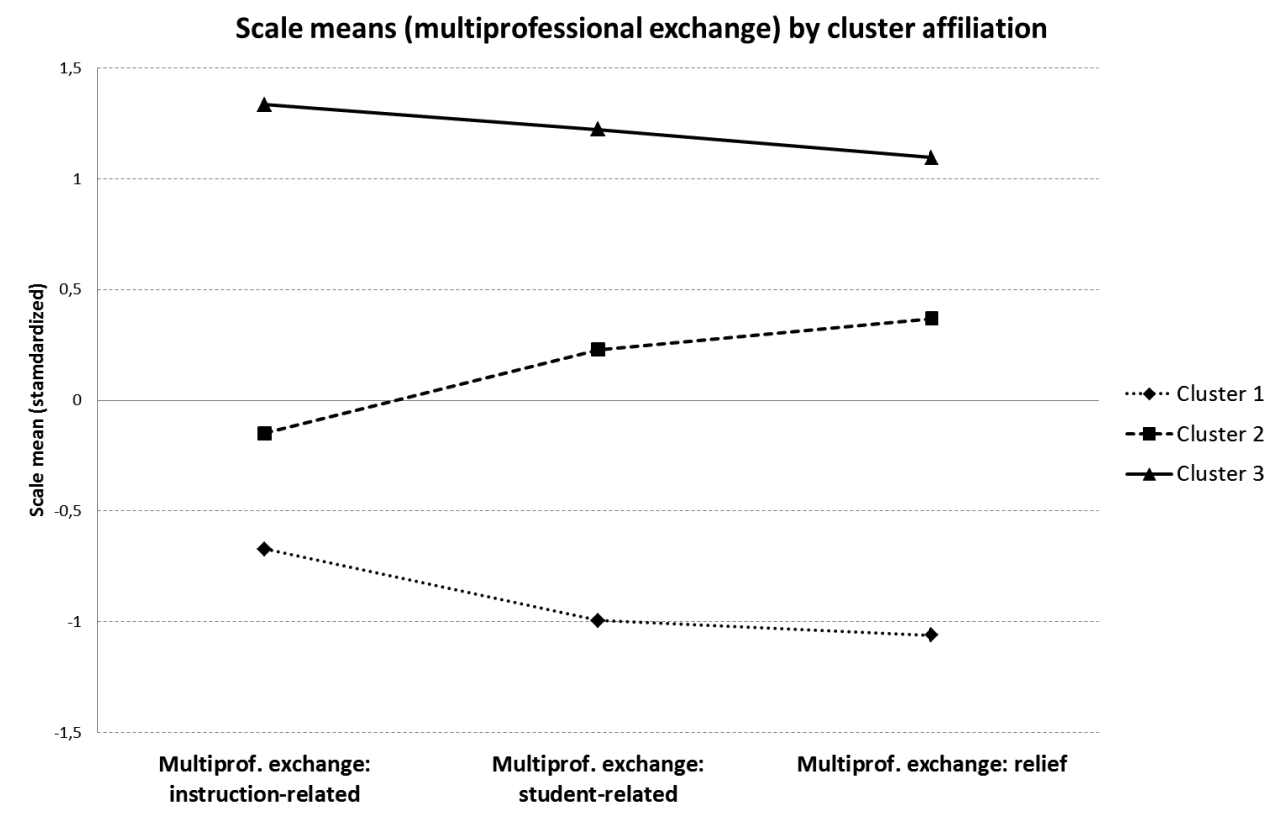

To identify more precisely which teaching staff make up the three clusters, their demographic and individual features were related to their cluster affiliation (see Tables 3 and 4$)$.

Table 3. Cluster affiliation and teacher sex

\begin{tabular}{lccc}
\hline & \multicolumn{2}{c}{ Teacher sex } & \\
\cline { 2 - 3 } & Female & Male & Total \\
\hline Cluster 1 & $38.5 \%(129)$ & $36.9 \%(75)$ & $37.9 \%(204)$ \\
Cluster 2 & $35.5 \%(119)$ & $44.8 \%(91)$ & $39.0 \%(210)$ \\
Cluster 3 & $26.0 \%(87)$ & $18.2 \%(37)$ & $23,0 \%(124)$ \\
\hline
\end{tabular}

Note: $c^{2}(2)=6.2, p<.05$.

As to the sex of the teaching staff, it has to be recorded that women were found more often in cluster 3 (the collaboration-active one) than men. The latter were predominantly found in cluster 2. With regard to the two age groups of the teaching staff ( 45 years and younger vs. 46 years and older), no significant difference in cluster affiliation was found (no Figure). 
Table 4. Cluster affiliation and teacher characteristics

\begin{tabular}{|c|c|c|c|c|c|}
\hline \multirow[b]{2}{*}{ Teacher characteristics } & \multicolumn{3}{|c|}{ Mean / (Standard Deviation) } & \multicolumn{2}{|c|}{ ANOVA } \\
\hline & Cluster 1 & Cluster 2 & Cluster 3 & $\begin{array}{c}F / \\
(p-\text { value })\end{array}$ & $\mathrm{Eta}^{2}$ \\
\hline Work commitment & $\begin{array}{c}4.74 \\
(1.01)\end{array}$ & $\begin{array}{c}4.79 \\
(1.02)\end{array}$ & $\begin{array}{l}4.98 \\
(.95)\end{array}$ & $\begin{array}{l}2.8 \\
(.056)\end{array}$ & .01 \\
\hline Self-efficacy & $\begin{array}{l}3.50 \\
(.68)\end{array}$ & $\begin{array}{l}3.61 \\
(.70)\end{array}$ & $\begin{array}{l}3.90 \\
(.75)\end{array}$ & $\begin{array}{l}13.8 \\
(<.05)\end{array}$ & .05 \\
\hline $\begin{array}{l}\text { Exchange between teachers: } \\
\text { student-related }\end{array}$ & $\begin{array}{l}4.91 \\
(.83)\end{array}$ & $\begin{array}{l}5.09 \\
(.69)\end{array}$ & $\begin{array}{l}5.33 \\
(.75)\end{array}$ & $\begin{array}{l}11.6 \\
(<.05)\end{array}$ & .04 \\
\hline $\begin{array}{l}\text { Exchange between teachers: } \\
\text { instruction-related }\end{array}$ & $\begin{array}{l}4.04 \\
(.99)\end{array}$ & $\begin{array}{l}4.28 \\
(.93)\end{array}$ & $\begin{array}{l}4.73 \\
(.90)\end{array}$ & $\begin{array}{l}20.6 \\
(<.05)\end{array}$ & .07 \\
\hline $\begin{array}{l}\text { Work shared between } \\
\text { teachers }\end{array}$ & $\begin{array}{c}2.98 \\
(1.26)\end{array}$ & $\begin{array}{c}3.30 \\
(1.28)\end{array}$ & $\begin{array}{l}3.88 \\
(1.28)\end{array}$ & $\begin{array}{l}19.3 \\
(<.05)\end{array}$ & .07 \\
\hline $\begin{array}{l}\text { Co-construction between } \\
\text { teachers }\end{array}$ & $\begin{array}{l}2.68 \\
(.92)\end{array}$ & $\begin{array}{l}2.85 \\
(.86)\end{array}$ & $\begin{array}{c}3.54 \\
(1.01)\end{array}$ & $\begin{array}{l}35.4 \\
(<.05)\end{array}$ & .12 \\
\hline $\begin{array}{l}\text { Goals shared between } \\
\text { teachers }\end{array}$ & $\begin{array}{l}4.15 \\
(.75)\end{array}$ & $\begin{array}{l}4.39 \\
(.69)\end{array}$ & $\begin{array}{l}4.46 \\
(.75)\end{array}$ & $\begin{array}{c}9.1 \\
(<.05)\end{array}$ & .03 \\
\hline
\end{tabular}

Note: Range for all scales: 1-6.

All the teacher characteristics investigated evinced the same pattern: the highest values are shown by members of cluster 3 . With the exception of work engagement all differences in the mean values between the three clusters are significant. We can sum up by saying that teachers, who have high profession-related self-efficacy and practice more demanding forms of collaboration (co-construction) with their colleagues, also have a greater probability of looking for collaboration with a school's other educational staff.

\section{Results of the Qualitative Study on Multiprofessional Collaboration and Professional Differences Seen From the Perspective of Teachers and Educators}

In the interview study the participating teachers and educators were first asked to describe their everyday work as well as that of the respective other professional group (RQ 2, see Table 5). In their narratives teachers and educators essentially agreed in their self and external assessments concerning their work. This was reflected in the sketches which the teachers gave of the tasks of both professional groups: they tended to see themselves as persons who pass on knowledge, while the other educational staff were seen as responsible, amongst other issues, for the promotion of the students' social and emotional competencies and for giving them guidance on how to give their afternoons and free time a meaningful shape.

The other educational staff gave a description of the work of the two professional groups that was similar to that of the teachers'. As was to be expected, the educators see their work in more differentiated terms than the teachers, underlining the fact that they are in charge of the children's holistic support (inter alia the promotion of their social behaviour, and the transmission of values and norms), the design of the 
afternoon programme as well as the improvement and upbringing of the children. This contrasts, so the educators, with the teachers' job, which they saw primarily to be that of the passing on of knowledge, as well as assessing and grading. These results are comparable to those known from the leisure-time centre research (Dahl \& Karlsudd, 2015) which also found separate professional competencies in the professional groups involved. Based on these findings, we went on to investigate the concrete shape of the multiprofessional collaboration and whether the findings were comparable to the assumptions of the first study (three different levels of multiprofessional collaboration). In this qualitative study, teachers and educators named the exchange of information as the predominant form of collaboration. Characteristic features of collaboration between teachers and educators are brief, spontaneous meetings or the writing of notes. A new finding was, however, that at schools where the morning programme dovetailed with that of the afternoon the interviewees reported a more intensive collaboration. Thus, the teaching staff divide up the labour in joint projects rather more at compulsory all-day schools than at open ones, or there are meetings with representatives of both professional groups. None of the interview partners, however, reported co-constructive collaboration.

Table 5. Implementation of multiprofessional collaboration from the perspectives of teachers and educators

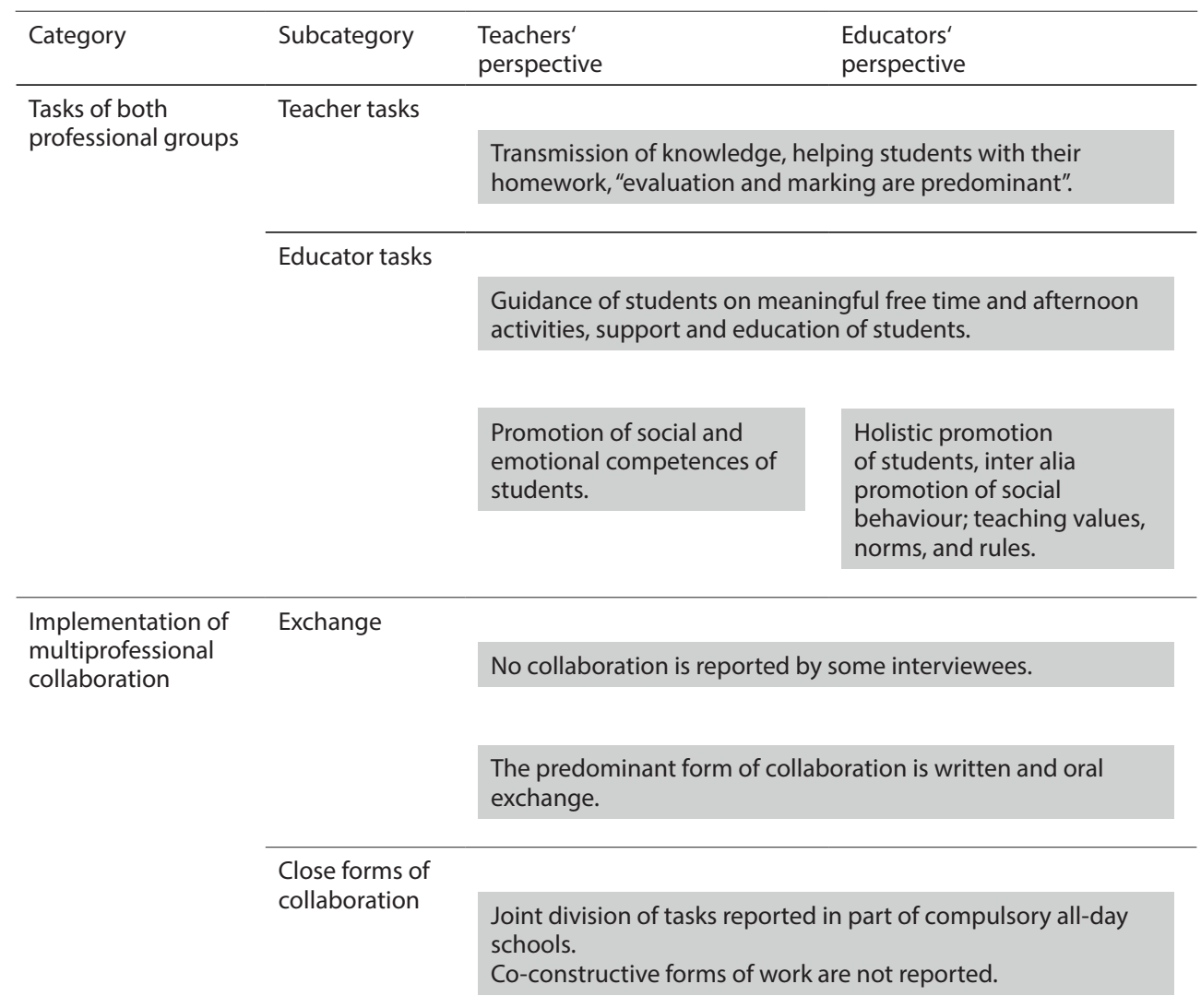


A further central concern of the interview study was to reveal diverging points of views and self-images as well as challenges posed by multiprofessional collaboration as seen from the perspective of teachers and educators (RQ 3, see Table 6). The two professional groups show different conceptions of collaboration as well as views of students and of what happens in class. One teacher reported, for example, that he would "do a lot of things differently" from the other educational staff in a joint teaching unit (Teacher 1, line 263). Because of the different approaches the collaboration "was funny at first" (T1, line 175). But as the collaboration went on, the differences in working style experienced were somewhat levelled which means that perceived differences would dissolve the longer the collaboration lasts:

"But the longer and closer you work together, the more you grow together" (T1, 1. 175).

Teachers and educators experienced their collaboration in general as positive. Both the teachers interviewed and the educators reported a good mutual relationship and appreciation in cooperative settings. When certain inadequate actions of the other professional group were mentioned, it tended to be on the part of the educators. Some educators reported, for instance, that in rare cases teachers were not prepared to work together with the other educational staff, that some teachers did not appreciate the educators' work or pulled rank on them. At schools, where the morning programme was dovetailed with the afternoon one, fewer difficulties were reported by the educators.

In another part of the interview, the teachers and educators were asked what shared goals and effects were linked to multiprofessional collaboration. This question aimed at a centrally important issue of collaboration itself. There was unanimity regarding the establishment of cooperative forms of work at their school as an independent goal to be pursued. Both teachers and educators agreed in seeing the existing collaboration as positive. Both groups also considered further meshing of their activities desirable.

The interviewees, again unanimously, identified the benefit that students can draw from the mutual exchange between teachers and educators, as well as the increased benefit for students if the collaboration were to be closer, as the central positive effect. The joint work makes an earlier, more intensive and individual support of the students feasible. It was possible to support students in individual subjects but also in other respects, for example in their social competence. Another positive effect, they stated, was that students learned that arrangements are made between teachers and the other educational staff. Uniform rules for the whole of the everyday life at the school could, therefore, be implemented by all actors:

"Well, I think that's also important, especially for children with problems that teachers and educators pull together" (Educator 3, line 195).

Through working together, both professional groups experienced additional enrichment of their own work. A feeling of encouragement by the other professional group is possible, it was argued, and through the exchange of experiences one could reap mutual benefit and extend one's own competences. Teachers in particular experience a sense of work relief through the mere presence of the other educational staff, es- 
pecially by delegating tasks and sharing responsibility. This last aspect, relief, is not reported explicitly by the other educational staff.

Table 6. Challenges, difficulties and goals of multiprofessional collaboration

\begin{tabular}{|c|c|c|c|}
\hline Category & Subcategory & $\begin{array}{l}\text { Teachers' } \\
\text { perspective }\end{array}$ & Educators' perspective \\
\hline \multirow{6}{*}{$\begin{array}{l}\text { Challenges and } \\
\text { difficulties of the } \\
\text { exchange }\end{array}$} & \multirow{2}{*}{$\begin{array}{l}\text { Harmonious working } \\
\text { relations }\end{array}$} & & \\
\hline & & \multicolumn{2}{|c|}{$\begin{array}{l}\text { Positive relations and mutual appreciation are predominant; } \\
\text { lack of free flow of information etc. is rarely mentioned. }\end{array}$} \\
\hline & \multirow{2}{*}{$\begin{array}{l}\text { Different working } \\
\text { methods and views }\end{array}$} & & \\
\hline & & \multicolumn{2}{|c|}{$\begin{array}{l}\text { Different working methods and views on things; different } \\
\text { methods and understandings of collaboration; these } \\
\text { differences can be overcome in the actual collaboration. }\end{array}$} \\
\hline & \multirow{2}{*}{$\begin{array}{l}\text { Lack of appreciation } \\
\text { of the work of the } \\
\text { all-day staff }\end{array}$} & & \\
\hline & & $\begin{array}{l}\text { Colleagues do not appreciate } \\
\text { the work of the educators. }\end{array}$ & $\begin{array}{l}\text { Some teachers do not } \\
\text { appreciate competences }\end{array}$ \\
\hline \multirow{9}{*}{$\begin{array}{l}\text { Effects of the } \\
\text { exchange }\end{array}$} & \multicolumn{3}{|l|}{ Global } \\
\hline & & \multicolumn{2}{|c|}{$\begin{array}{l}\text { Collaboration as such is regarded as desirable and experienced } \\
\text { as positive. }\end{array}$} \\
\hline & \multicolumn{3}{|l|}{ Student-related } \\
\hline & & \multicolumn{2}{|c|}{$\begin{array}{l}\text { Students benefit most; better support is made possible; staff- } \\
\text { student interaction from one source }\end{array}$} \\
\hline & \multicolumn{3}{|l|}{ Staff-related } \\
\hline & & \multicolumn{2}{|c|}{$\begin{array}{l}\text { Broadening of one's own competences and perspective. } \\
\text { Emotional relief through shared responsibility. }\end{array}$} \\
\hline & & Work-load relief & (Not reported) \\
\hline & \multirow{2}{*}{$\begin{array}{l}\text { Teaching- and offer- } \\
\text { related }\end{array}$} & & \\
\hline & & \multicolumn{2}{|l|}{ No effects tended to be noted. } \\
\hline
\end{tabular}




\section{Discussion}

Beyond normative discussions about the value and the intended educational impact of cooperative actions at schools, the collaboration of different professions at German all-day schools has become a de facto challenge for the future implementation of the professionalism of teaching staff. In the two studies presented, we tackled three research questions using a mixed methods design.

The analysis of the levels of multiprofessional collaboration seen from the teachers' point of view shows that exchange seems to be the predominant form of collaboration. This is supported by both the qualitative and quantitative findings. This rather low cost type of collaboration is due not least to the organization of all-day learning at German schools: With the exception of the comprehensive schools, the open model of all-day schools is predominant (Autorengruppe Bildungsberichterstattung, 2014). Content-wise, this means that there is an organizational and a conceptual separation of teaching in the morning and educational support in the afternoon. These results are in accordance with previously published studies of multiprofessional collaboration in schools (Forrer \& Schuler, 2010; Jutzi, Schüpbach, \& Thomann, 2013; Schüpbach \& von Allmen, 2013) or in other extended education contexts (e.g. leisure-time centres in Sweden; Dahl \& Karlsudd, 2015).

The results of our qualitative study indicate that compulsory all-day schools (where teaching and educational support are linked in conceptual and organizational terms) practice rather more demanding forms of collaboration. Although multiprofessional collaboration is mostly situated at the level of exchange, it is perceived as positive by the teaching staff at all-day schools. The teaching staff perceive some relief from their work, particularly through the delegation of tasks that are not related to instruction but to educational tasks in the wider sense. One has, however, to raise the question of whether this attitude is in line with the demands formulated by Sachs (2003) regarding the core elements of teacher professionalism. If collaboration with other professional groups is to contribute to an increase in teachers' knowledge and competences, the delegation of tasks, and thus the concentration on supposedly explicitly teacher-related work areas, is hardly the right way to achieve the generation of co-constructive knowledge by members of different professions. This diagnosis is supported by the analysis of the quantitative data. Teaching staff see their explicit brief in the transmission of knowledge whereas the other educational staff bring the promotion of social and emotional competences to the fore of their professional work. Our findings show a great correspondence to the study results of Dahl \& Karlsudd (2015) in which the educational professionals emphasise the importance of separate consideration of professional groups in leisure-time centres.

Fewer than one in four $(23 \%)$ of the teaching staff interviewed in the quantitative survey can be assigned to a collaboration-active cluster. The teachers in this cluster collaborate both in their teaching and their support of individual students with the other educational staff. In addition, these teachers tend to be female and are of high professional self-efficacy. Collaboration in general seems to come to them more naturally than to other teachers. This group of teachers also reports the highest degree of relief through collaborative activities. This finding indicates that the added value 
of collaborative action does not arise until collaboration is undertaken with a certain degree of energy and seriousness.

The diverging perceptions of the different professional groups in all-day schools concerning the respective work areas are reflected in the type of collaboration used: The discussion of the qualitative data shows that collaborative action between the teaching and the other educational staff is located predominantly at the level of exchange. This result is to be understood as indicating that it is not just the form of the organization of German all-day schools that has an influence on the collaborative activities of different professions, but also the way teachers and others perceive their respective tasks. Higher forms of collaboration (division of labour and co-construction) are mainly appropriate when the educational staff of the schools share a common definition of tasks and goals.

Not only the diverging perception of tasks, but also further problems that are located at the level of the individual educator make a more intensive collaboration between the two groups difficult. Our qualitative content analysis shows that the members of the other educational staff in particular report a lack of recognition of their work on the part of teachers and the latter's hierarchical understanding of their roles. The definition of collaboration we used (Spieß, 2004) indicates that trust and reciprocity are important factors of successful collaboration. As soon as one partner of the collaboration feels that he/she invests more in the collaboration than the other people while also receiving less acknowledgement of his/her work, collaboration will not have any added value for this actor. In the findings of our qualitative study only teachers, but not the other educational staff, reported relief through the collaboration. A further qualitative result is the lack of an explicit link to collaborative action in multiprofessional settings. Multiprofessional collaboration as such is regarded as valuable and aims for a more intensive support of students. But it is extremely rare to find statements in the interviews that are related to collaboration based on co-construction or the division of labour. What is predominant is the satisfaction of teachers with the presence of other professions at their schools, and as a corollary, the possible support of their own work.

Summing up in relation to our overall research question, the results of both studies show that exchange is the most common way of multiprofessional collaboration between teachers and the other educational staff in all-day schools. Only in closely coupled teams of teachers and other educational staff (mainly educators in compulsory all-day schools) higher forms of collaboration (division of labour and co-construction) are observable.

However, despite of the relative lack of genuine multiprofessional collaboration educational actors perceive positive effects: Teachers feel relieved and both professional groups report beneficial effects (mainly in social issues) in favour for the students. On the other hand, also negative effects were mentioned by the interviewees: Especially the other educational staff are worried about the separation of professional responsibilities by the organization of all-day schooling. While the regular instruction (in the morning) remains the domain of the teachers, the other educational staff are responsible for afternoon education and care. In light of these findings, a rhythmic all-day school life and a joint schooling will be difficult to establish. 
Furthermore, the other educational staff are concerned about a instrumentalisation by the teachers: Teachers commonly perceive only instruction in the focus of their professional competence. However, student-related problems are often delegated to the other educational staff. Both findings (separation and delegation) are contrary to the ideal of a reciprocal and trustful collaboration between different professions (Spieß, 2004) in all-day schools. Joint training courses of teachers and other educational staff and the use of intervention studies are to be viewed as options to achieve a sustained strengthening of multiprofessional collaboration in all-day schools.

\section{Limitations of the Present Studies}

Work on the three research questions was carried out applying qualitative and quantitative methods. As for our qualitative findings, the universally acknowledged limits of the generalizability of qualitative results also apply to the present article. Our quantitative findings show, however, a high degree of agreement with the qualitative ones: the low-level multiprofessional collaboration (exchange) and the relief through this form of collaboration perceived by the teachers were mentioned both in the interview study and in the quantitative survey. A limitation of the quantitative study was the fact that it is a cross-sectional study designed to serve above all the development of a measuring instrument for multiprofessional collaboration. This is why our views on the relations between forms of collaboration themselves, further personal characteristics of the teaching staff as well as the relief provided by multiprofessional collaboration can be given only in the form of correlations. The link between the quantitative and the qualitative study is not a comparable sample, but the phenomenon of multiprofessional collaboration. It can be assumed that our qualitative findings are not only valid for primary schools, but for challenges and opportunities of collaborative work between teachers and the other educational staff in general. However, a reliable generalization of the qualitative findings to other types of schools would not be appropriate. Future research may help to overcome the limitations of the present study by the longitudinal consideration of the extent and effect of multiprofessional collaboration and by appropriate qualitative investigation plans (for example observation).

\section{References}

Andersson, B. (2010). Introducing assessment into Swedish leisure-time centres - pedagogues' attitudes and practices. Education Inquiry, 1(3),197-209. http://dx.doi.org/10.3402/edui.v1i3.21942

Arnoldt, B. (2009). Der Beitrag von Kooperationspartnern zur individuellen Förderung an Ganztagsschulen. In L. Stecher, C. Allemann-Ghionda, E. Klieme \& W. Helsper (Eds.), Ganztägige Bildung und Betreuung (pp. 63-80). Weinheim: Beltz. (Zeitschrift für Pädagogik, Beiheft, 54). 
Autorengruppe Bildungsberichterstattung (2014). Bildung in Deutschland 2014. Ein indikatorengestützter Bericht mit einer Analyse zur Bildung von Menschen mit Behinderungen. Bielefeld: Bertelsmann.

Bae, S. H., \& Jeon, S. B. (2013). Research on Afterschool Programs in Korea. International Journal for Research on Extended Education, 1(1), 53-69.

Beher, K., \& Rauschenbach, T. (2006). Die offene Ganztagsgrundschule in Nordrhein-Westfalen. Ein gelungenes Zusammenspiel von Schule und Jugendhilfe? Zeitschrift für Erziehungswissenschaft, 9(1), 51-66. http://dx.doi.org/10.1007/ s11618-006-0004-5

Beher, K., Hänisch, H., Hemens, C., Nordt, G., Prein, G., \& Schulz, U. (2007). Die offene Ganztagsschule in der Entwicklung: Empirische Befunde zum Primarbereich in Nordrhein-Westfalen. Weinheim: Juventa.

Böhm-Kasper, O., Dizinger, V., \& Heitmann, V. (2013). Interprofessionelle Kooperation an offenen und gebundenen Ganztagsschulen. Zeitschrift für Grundschulforschung, 6(2), 53-68.

Böttcher, W., Maykus, S., Altermann, A., \& Liesegang, T. (2011). Multiprofessionelle Kooperation an Ganztagsschulen. In K. Speck, Th. Olk, O. Böhm-Kasper, H.-J. Stolz \& C. Wiezorek (Eds.), Ganztagsschulische Kooperation und Professionsentwicklung. Studien zu multiprofessionellen Teams und sozialräumlicher Vernetzung (pp. 102-113). Weinheim: Juventa.

Čandová, A. (2005). Determinanten der beruflichen Belastung bei jungen Lehrerinnen und Lehrern - Eine Längsschnittstudie (Dissertation). Friedrich-Alexander-Universität Erlangen-Nürnberg, Nürnberg.

Creswell, J. W., \& Plano Clark, V. L. (2011). Designing and conducting mixed methods research. Los Angeles: Sage.

Dahl, M., \& Karlsudd, P. (2015). Leisure-time teachers in a changed profession. Problems of education in the 21st century, (68), 22-35.

Demirkasımoğlu, N. (2010). Defining "Teacher Professionalism" from different perspectives. Procedia - Social and Behavioral Sciences, 9, 2047-2051. http://dx. doi.org/10.1016/j.sbspro.2010.12.444

Dizinger, V. (2015). Professionelle und interprofessionelle Kooperation von Lehrerinnen und Lehrern im Kontext schulischer Belastung und Beanspruchung (Dissertation). Universität Bielefeld, Bielefeld.

Dizinger, V., Fussangel, K., \& Böhm-Kasper, O. (2011). Lehrer/in sein an der Ganztagsschule: Neue Kooperationsanforderungen - neue Belastungen? Zeitschrift für Erziehungswissenschaft, 14(3), 43-61. http://dx.doi.org/10.1007/s11618011-0227-y

Durlak, J. A., \& Weissberg, R. P. (2007). The Impact of After-School Programs That Promote Personal and Social Skills. Collaborative for Academic, Social, and Emotional Learning (CASEL): Chicago.

Englund, T. (1996). Are Professional Teachers a Good Thing? In I. Goodson \& A. Hargreaves (Eds.), Teachers' professional lives (pp. 75-87). London: Falmer Press.

Flowers, N., Mertens, S. B., \& Mulhall, P. F. (2000). What Makes Interdisciplinary Teams Effective? Middle School Journal, 31(4), 53-56. http://dx.doi.org/10.108 0/00940771.2000.11494640 
Forrer, E., \& Schuler, P. (2010). Schlussbericht Evaluation Schülerclubs und Tagesschulen in der Stadt Zürich. Pädagogische Hochschule Zürich, Zürich.

Fussangel, K. (2008). Subjektive Theorien von Lehrkräften zur Kooperation. Eine Analyse der Zusammenarbeit von Lehrerinnen und Lehrern in Lerngemeinschaften (Dissertation). Bergische Universität Wuppertal, Wuppertal.

Gerecht, M., Steinert, B., Klieme, E., \& Döbrich, P. (2007). Skalen zur Schulqualität: Dokumentation der Erhebungsinstrumente: Pädagogische Entwicklungsbilanzen mit Schulen (PEB). Frankfurt am Main. Retrieved from http://www. pedocs.de/volltexte/2010/3121/pdf/MatBild_Bd17_D_A.pdf.

Gläser, J., \& Laudel, G. (2004). Experteninterviews und qualitative Inhaltsanalyse als Instrumente rekonstruierender Untersuchungen. Wiesbaden: VS Verlag.

Gräsel, C., Fussangel, K., \& Pröbstel, C. (2006). Lehrkräfte zur Kooperation anregen - eine Aufgabe für Sisyphos? Zeitschrift für Pädagogik, 52(2), 205-219.

Hesjedal, E., Hetland, H., \& Iversen, A. C. (2013). Interprofessional collaboration: self-reported successful collaboration by teachers and social workers in multidisciplinary teams. Child \& Family Social Work, 20, 437-445. http://dx.doi. org/10.1111/cfs. 12093

Holtappels, H. G., Klemm, K., \& Rolff, H.-G. (2008). Schulentwicklung durch Gestaltungsautonomie: Ergebnisse der Begleitforschung zum Modellvorhaben ,Selbstständige Schule' in Nordrhein-Westfalen. Münster: Waxmann.

Holtappels, H. G., Krinecki, J., \& Menke, S. (2013). Lernkultur, Kooperationen und Wirkungen: Befunde aus der Ganztagsschulforschung. Berlin. Retrieved from https://www.dkjs.de/fileadmin/Redaktion/Dokumente/programme/140422_ doku8 lernkultur.pdf.

Hord, S. M. (1997). Professional learning communities: Communities of continuous inquiry and improvement. Austin, Texas: Southwest Educational Development Laboratory.

Horstkemper, M. (2011). Multiprofessionelle Kooperation an Ganztagsschulen: Herausforderung und Chance für Schul- und Professionsentwicklung. In K. Speck, Th. Olk, O. Böhm-Kasper, H.-J. Stolz \& C. Wiezorek (Eds.), Ganztagsschulische Kooperation und Professionsentwicklung. Studien zu multiprofessionellen Teams und sozialräumlicher Vernetzung (pp. 128-137). Weinheim: Juventa.

Jutzi, M., Schüpbach, M., \& Thomann, K. (2013). Bedingungen multiprofessioneller Kooperation in zehn Schweizer Tagesschulen. In M. Schüpbach, A. Slokar \& W. Nieuwenboom (Eds.), Kooperation als Herausforderung in Schule und Tagesschule (pp. 95-110). Bern: Haupt.

Klerfelt, A., \& Haglund, B. (2014). Presentation of Research on School-Age Educare in Sweden. International Journal for Research on Extended Education. $2(1), 45-62$.

Knauer, R. (2010). Kooperation von Jugendhilfe und Schule im Spannungsfeld unterschiedlicher Anforderungen. In U. Deinet \& M. Icking (Eds.), Jugendhilfe und Schule. Analysen und Konzepte für die kommunale Kooperation (pp. 3553). Opladen: Budrich.

Lichtman, M. (2013). Qualitative Research in Education: A User's Guide. Thousand Oaks, California: Sage. 
Lütje-Klose, B., \& Urban, M. (2014). Kooperation als wesentliche Bedingung inklusiver Schul- und Unterrichtsentwicklung. Teil 1: Grundlagen und Modelle inklusiver Kooperation. Vierteljahrsschrift für Heilpädagogik und ihre Nachbargebiete, (83), 112-123.

Maykus, S. (2009). Kooperation: Mythos oder Mehrwert? Der Nutzen multiprofessioneller Kooperation der Akteure schulbezogener Jugendhilfe. In F. Prüß, S. Kortas \& M. Schöpa (Eds.), Die Ganztagsschule: von der Theorie zur Praxis. Anforderungen und Perspektiven für Erziehungswissenschaft und Schulentwicklung (pp. 307-321). Weinheim: Juventa.

Mayring, P. (2008). Qualitative Inhaltsanalyse: Grundlagen und Techniken. Weinheim: Beltz.

Ogenchuk, M., Spurr, S., \& Bally, J. (2014). Caring For Kids Where They Live: Interprofessional collaboration in teaching and learning in school settings. Nurse Education in Practice, 14(3), 293-298. http://dx.doi.org/10.1016/j.nepr.2013.11.003

Reh, S. (2008). "Reflexivität der Organisation" und Bekenntnis. Perspektiven der Lehrerkooperation. In W. Helsper (Eds.), Pädagogische Professionalität in Organisationen. Neue Verhältnisbestimmungen am Beispiel der Schule (pp. 163183). Wiesbaden: VS Verlag. http://dx.doi.org/10.1007/978-3-531-90777-2_9

Reh, S., \& Breuer, A. (2012). Positionierungen in interprofessionellen Teams Kooperationspraktiken an Ganztagsschulen. In S. G. Huber \& F. Ahlgrimm (Eds.), Kooperation. Aktuelle Forschung zur Kooperation in und zwischen Schulen sowie mit anderen Partnern (pp. 185-201). Münster: Waxmann.

Sachs, J. (2003). The activist teaching profession. Professional learning. Buckingham: Open University Press.

Schüpbach, M., \& von Allmen, B. (2013). Swiss National Report on Research on Extended Education. International Journal for Research on Extended Education, 1(1), 18-30.

Speck, K., Olk, Th., Böhm-Kasper, O., Stolz, H.-J., \& Wiezorek, C. (2011). Multiprofessionelle Teams und sozialräumliche Vernetzung? In K. Speck, Th. Olk, O. Böhm-Kasper, H.-J. Stolz \& C. Wiezorek (Eds.), Ganztagsschulische Kooperation und Professionsentwicklung. Studien zu multiprofessionellen Teams und sozialräumlicher Vernetzung. Weinheim: Juventa.

Spieß, E. (2004). Kooperation und Konflikt. In H. Schuler (Eds.), Enzyklopädie der Psychologie, Themenbereich D (pp. 193-247). Göttingen: Hogrefe.

Steiner, Ch. (2010). Multiprofessionell arbeiten im Ganztag: Ideal, Illusion oder Realität? Der pädagogische Blick, 18(1), 22-69.

Tillmann, K., \& Rollett, W. (2011). Multiprofessionelle Kooperation und Partizipation an Ganztagsschulen - Welche Auswirkungen hat die strukturelle Einbindung des weiteren pädagogischen Personals auf die berufsübergreifende Zusammenarbeit? In K. Speck, Th. Olk, O. Böhm-Kasper, H.-J. Stolz \& C. Wiezorek (Eds.), Ganztagsschulische Kooperation und Professionsentwicklung. Studien zu multiprofessionellen Teams und sozialräumlicher Vernetzung (pp. 29-47). Weinheim: Juventa.

Tuomainen, J., Palonen, T., \& Hakkarainen, K. (2010). A Special Education Teacher's Networks: A Finnish Case. International Journal of Special Education, 25(1), 46-58.

Whitty, G. (2000). Teacher professionalism in new times. Journal of In-Service Education, 26(2), 281-295. http://dx.doi.org/10.1080/13674580000200121 